\title{
Üniversite Öğrencilerinde Riskli Kafein Tüketimi
}

\author{
Birgül AYDIN ${ }^{1}$, Gül ERYILMAZ ${ }^{2}$
}

Özet: Üniversite öğrencilerinin riskli kafein tüketimi örüntüsünü incelemek, bu örüntünün kafein tüketme alışkanlıkları ve riskli kafein kullanımı ile ilişkilerini araştırmak amacı ile yapılımıştır. Betimsel araştırma modeli kullanılmış olup, elverişli örneklem yöntemi ile veri toplanmıştır. Veri toplama aracı olarak anket formu kullanılmış ve verilerin analizi SPSS 20 paket programı ile yapılmıştır. Sigara kullanımı, sigara/kahve kullanmaya başlama önceliği, kafein tüketilmediğinde ya da az tüketildiğinde 24 saat içinde görülen belirtilerden depresif mod/sinirlilik belirtisi ve konsantrasyon zorluğu belirtisi ile riskli kafein tüketimi arasında istatistiksel olarak anlamlı ilişki elde edilmiş̧ir. Araştırma sonunda üniversite öğrencilerinin \%20' sinin riskli kafein tüketimi kriterlerini karşıladığı ve kafein bağımlılı̆̆ için risk grubunda oldukları bulunmuştur. Bu çalışma ve benzeri çalışmaların, daha geniş bir örneklem ve farklı değişkenler ile yapılması önerilmektedir.

Anahtar kelimeler: Riskli kafein tüketimi, üniversite öğrencileri, bağımlılık.

\section{Risky Caffeine Consumption of the University Students}

\begin{abstract}
The aim of this study is to examine the risky caffeine consumption patterns of the university students, and to study the relationship of this pattern with caffeine consumption habits and risky caffeine consumption. Descriptive research model has been used. Data were collected through the method of convenience sampling. Risky caffeine consumption questionnaire developed by the researcher is used as the data collection tool. There is a correlation between cigarette smoking, precedence of starting cigarette smoking/coffee consumption, the sign of depressive mood/nervousness, the sign of hardship of concentration, among the signs which are observed within 24 hours and risky caffeine consumption. The study gives significant information about the formation of risky caffeine consumption habits among the university students nearly $\% 20$ percent of them are in this group. This study suggests similar studies will be done with broader sample and with different variables.
\end{abstract}

Key words: Risky caffeine consumption, university students, addiction.

${ }^{1}$ Psk., Üsküdar Üniversitesi, İstanbul

${ }^{2}$ Uzm. Dr., NP İstanbul Beyin Hastanesi

Address of correspondence/ Yazışma adresi: Psk, Birgül Aydın, Üsküdar Üniversitesi Bağımlılık Danışmanlığı ve Rehabilitasyon Yüksek Lisans Programı Öğrencisi, E-mail: kelebekceesinti@gmail.com

Date of Received/Geliş Tarihi: 19.10.2019, Date of Revision/Düzeltme Tarihi: 02.11.2019, Date of Acceptance/Kabul Tarihi: 06.11.2019

Citing/ Referans Gösterimi: Aydın, B., Eryılmaz G. (2019).Üniversite Öğrencilerinde Riskli Kafein Tüketimi. Kıbrls Türk Psikiyatri ve Psikoloji Dergisi, 1(Özel Sayl.1): 19-23 doi:10.35365/ctjpp.19.special1.5 


\section{Giriş}

Kimyasal olarak acı tat grubuna giren kafein ve bu gibi acılık maddeleriyle hazırlanan içecekler, tat duyusu üzerinde bıraktıkları serinletici etkiden dolayı toplumun büyük bir çoğunluğu tarafından yaygın bir şekilde kullanılır (Eskigün ve Bayrak, 2006). Kafein çoğunlukla da çay, kahve, kola, çikolata, enerji içeceği ve soğuk çay şeklinde tüketilir.

Kahve en önemli kafein kaynaklarının başında gelmektedir. Bağımlılık yapan maddeler arasında, dünyada yasal yollardan kullanılan en yaygın içecektir. Satışı ve kullanılışında herhangi bir kısıtlamanın olmayış1 tüketimini daha da artırmaktadır (Uzbay, 2015).

Kafein bağımlılığının temeli çocuklukta çikolata ile atılırken, ergenlerde kola ve soğuk çay ile pekişir. Daha ileri yaşlarda ise çay ve kahve tüketimi ile daha ileri düzeye taşınır. Kafein kişinin fiziki ve mental durumuna etki etmesi sebebiyle yoğun ilgi görmektedir (Hancı ve ark., 2013). Misafire çay ve kahve ikramı tarihsel kültürümüzden kalma bir mirasımızdır. Bunun yanında özellikle Ramazan ayında reklamlarda kolanın, iftar yemeğinin içeceği olarak sunulması da amacına hizmet ederek kolayı yemeklerin yanında içilecek bir içecek olarak algılamamızı sağlamıştır. Enerji içeceklerinin bilinçli olarak reklamlar yoluyla sporcu ve gençlerle yan yana getirilmesi de kafein kullanım oranlarının artmasına katkıda bulunmuştur. Bu ürünlerin satışını artırmak için, pazarlama tekniği olarak spor kulüplerinin taraftarlarına özel, tuttukları takımın simgesini içeren süslü ambalajlarda sunulması tüketimini artıran diğer bir faktördür. Ancak etik ve yasal boyutu tartışmalıdır (Uzbay, 2015). Kafein aynı zamanda reçeteli ve reçetesiz satılan 1000 den fazla ilaçta sinir sistemini uyarıcı, ağrı kesici ilaçların etkisini artırıcı, solunum sistemi zorluklarını giderici bir madde olarak da kullanılmaktadır.

Genel olarak kafeininin insan sağlığ etkileri olduğuna inanılmaktadır. Yorgunluğu azalttı̆̆ı, uyanıklık süresini uzattığ kuvvetlendirdiği, bedensel çalışmaları güçlendirdiği yönünde çalışmalar mevcuttur. $\mathrm{Bu}$ da üniversite öğrencileri arasında kafeinin neden bu denli popüler şekilde tüketildiğini anlamamıza yardımcı olmuştur.

Ergenlikten yetişkinliğe geçiş döneminin sancılarını yaşayan üniversite öğrencilerinin, her yaş grubunda olduğu gibi, hatta tüm dünyada olduğu gibi temel uyarıcı kaynağı kafeindir. $\mathrm{Bu}$ da örneklem olarak üniversite ögrencilerinin seçilmesi gerekliliğini ortaya koymuştur.

Zaten kültürel etkiler, reklamlar gibi sağlam bir temelle, alışık oldukları ortamdan farklı bir ortama geçişin yarattığı adaptasyon sorunları ve akran baskısı ile karı karşıya kalan, sunum hazırlayan, sınavlara hazırlanan öğrenciler odaklanabilmek ve uzun saatler uyanık kalabilmek için uyarıcı olarak kafeini tercih etmekte ve bu tercihlerini de genelde çay, kahve, soğuk çay, enerji içeceği ve kafein tabletleri alarak hayata geçirmektedirler. İçilerek kullanılan bu kafein tabletlerinin her biri $200 \mathrm{mg}$ kadar kafein içermektedir.

DSM-5 tanı ölçütlerinde kafein intoksikasyonu aşırı miktarda kafein tüketimi sonrası ortaya çıkan semptomlar şeklinde tanımlanmış ve bu semptomların son alınan yüksek doz kafein düzeyi (<250 mg) ile ilişkili olması gerektiği belirtilmiştir (Coşkunol 2018). Günde 250 mg' lık dozu geçmek kafein bağımlılığına zemin hazırlayan en önemli sebeplerdendir.Yan etkilere yol açabileceğinden, tehlikeli sınır günde 1 gr tüketilmesidir (Bolton ve Null, 1981).Amerikan Gida ve İlaç Dairesi (FDA) 2007' de, güvenli kafein miktarın $100 \mathrm{mg}$. olarak kabul ettiğini açıklamıştır (Pennay ve Lubman, 2012). Bu çalışmada günlük riskli kafein tüketim limiti $250 \mathrm{mg}$ olarak ele alınmıs ve $250 \mathrm{mg}$ kafeininde ortalama $500 \mathrm{ml}$ kafeinli içecekten alınabileceğinden hareket edilmiștir.

Güvenli günlük kafein kullanım miktarının $100 \mathrm{mg}$, bağımlılığa zemin hazırlayan en önemli sebeplerden birinin 250 mg' dan fazla kullanım, $500 \mathrm{ml}$ ' den fazlasının riskli kullanım ve 1 gr' in tehlikeli kullanım sınırı olduğu düşünüldüğünde, üniversite öğrencilerinin nasıl bir tehlike ile karşı karşıya oldukları daha iyi anlaşılmaktadır

Yapılan literatür taramasında geçmiş yıllarda kafenin kullanımı ile ilgili çeşitli çalışmaların yapıldığı, ancak DSM-5' e giren kafein yoksunluğu ile ilgili yeterli çalışmanın yapılmadığı görülmüştür. Bu açıdan bilişsel, psikolojik ve nörobiyolojik yönleri de bulunan kafein bağımlılı̆̆ 1 ve zeminini oluşturan riskli kafein tüketimi alanında yapılan bu çalışmanın, üniversite öğrencilerinde riskli kafein tüketme alışkanlığının oluşmasına dair önemli bilgiler sunması açısından önemli olduğu düşünülmektedir.

Aslında kahvaltılarda kültürümüzden gelme çay tüketimi, misafire çay ve kahve ikramı, çocukların çikolata ve kolaya olan düşkünlüğü, yemeklerin yanında içecek olarak kolanın sunulması, gençliğin enerji ile özdeşleşip enerji içeceklerine kayması, ofis çalışanlarında dinlenmenin artık kahve molası şeklinde bir ritüele dönüşmesi, tedavi amaçlı kafein içeren birtakım ilaçların kullanımı, üniversite öğrencilerinin sınav ve performans kaygısıyla kahve, enerji içecekleri ve kafein tabletlerine yönelimi ilk başlarda masum gibi görünsede, artık günümüzde görünmeyen tehlike gün yüzüne çıkmış durumdadır. Öyle ki kafein daha ileriki çalışmalar için bir koşul olarak, Kafein Kullanım Bozukluğu adıyla DSM-5 teki yerini almıştır (Coşkunol, 2018).

\section{Yöntem}

Betimsel araştırma modeli kullanılmıştır. Elverișli örneklem yöntemi ile, İstanbul ili sınırları içinde bulunan Üsküdar üniversitesinin çeşitli fakülte ve değişik bölümlerinde öğrenim gören gönüllü 204 lisans öğrencisinden veri toplanmıştır. Veriler araştırmacı tarafindan oluşturulan ve uzman görüşüne başvurularak tekrar revize edilen "Riskli Kafein Kullanımı Anketi" uygulanarak toplanmıştır. Toplanan veriler SPSS Programında değerlendirilmiş, sayısal ve yüzdelik dağılımlar ile ortalamaları hesaplanmıştır.

\section{Bulgular}

Kafein kaynağı olarak; gün içinde tüketilen çay, kahve, türk kahvesi, çikolata ve enerji içeceğine göre en çok tüketilen çay olup tüm grubun \%81'ini oluşturmaktadır. Çikolata tüketen tüm grubun \%53'ünü, kahve tüketen 52'sini, Türk kahvesi tüketen 39'unu ve enerji içeceği tüketen ise \%4'ünü oluşturmaktadır. Öğrencilerin sigara kullanımı ile riskli kafein tüketimiarasında ilişki vardır ve sigara içme oranı arttıkça kafein tüketimi de artmaktadır $\left(X^{2}(2)=6.052, \mathrm{p}=.049, \mathrm{p}<.05\right)$. 
Tablo 1: Sigara kullanımı ve Sigara/Kahve kullanmaya başlama önceliği ile kafein tüketimi arasında ki-kare tablosu

\begin{tabular}{llcccc}
\hline Değişken & Grup & Normal Kullanım & Riskli Kullanım & Ki-Kare & sd \\
\hline \multirow{2}{*}{ Sigara Kullanım } & Evet & $31 \%$ & $51 \%$ & 6,052 & 2 \\
& Hayır & $69 \%$ & $49 \%$ & & \\
\hline \multirow{2}{*}{ Sigara/Kahve Önceliği } & Sigara & $23 \%$ & $39 \%$ & 5,845 & 1 \\
& Kahve & $77 \%$ & $61 \%$ & & \\
\hline \multirow{2}{*}{ p $<.05$} & & & &
\end{tabular}

Sigara kullanma durumu ile öğrencilerin kafein tüketimi arasında istatistiksel olarak anlamlı ilişki elde edilmiştir $\left(X^{2}(2)=6.052, \mathrm{p}=.049, \mathrm{p}<.05\right)$. Sigara kullanan öğrenciler için, riskli olarak kafein tüketen öğrencilerin oranı normal olarak kafein tüketen öğrencilerin oranından daha yüksektir. Sigara kullanmayanlarda ise normal olarak kafein tüketenlerin oranı, riskli olarak kafein tüketenlerin oranından daha yüksektir. Yani riskli olarak kafein tüketme ile sigara içme ilişkilidir ve sigara içme oranı arttıkça tüketilen kafein miktarı da artmaktadır.
Sigara/kahve kullanmaya başlama önceliği ile öğrencilerin kafein tüketimi arasında ilişki anlamlıdır ve önce sigara içmeye başlayan öğrenciler için; riskli olarak kafein tüketen öğrencilerin oranı, normal olarak kafein tüketen öğrencilerin oranından daha yüksektir $\left(X_{(I)}^{2}=\right.$ $5.845, \mathrm{p}=.042, \mathrm{p}<.05)$.

Öğrencilerde kafein tüketilmediğinde ya da az tüketildiğinde 24 saat aralığında görülen belirtilerden, depresif mod ve sinirlilik belirtisi ile kafein tüketimi arasında istatiksel olarak anlamlı ilişki vardır $\left(X_{(I)}^{2}=\right.$ 9.408, $\mathrm{p}=.003, \mathrm{p}<.05)$.

Tablo 2: Depresif mod ve sinirlilik belirtisi ile kafein tüketimi arasındaki ilişki

\begin{tabular}{|c|c|c|c|c|c|c|}
\hline Değişken & Grup & Normal Kullanım & Riskli Kullanım & Ki-Kare & sd & $\mathrm{p}$ \\
\hline \multirow{2}{*}{ Depresif Mod ve Sinirlilik } & Evet & $13 \%$ & $33 \%$ & 9,408 & 1 & $0,003 *$ \\
\hline & Hayır & $87 \%$ & $68 \%$ & & & \\
\hline \multirow{2}{*}{ Konsantrasyon Zorluğu } & Evet & $12 \%$ & $30 \%$ & 7,81 & 1 & $0,005^{*}$ \\
\hline & Hayır & $88 \%$ & $70 \%$ & & & \\
\hline
\end{tabular}

*p<.05

Son olarak kafein tüketilmediğinde ya da az tüketildiğinde 24 saat aralığında görülen konsantrasyon zorluğu belirtisi ile riskli kafein tüketimi arasında ilişki anlamlıdır ve bu belirti oranları riskli kafein tüketimi yapan ögrencilerde daha yüksektir $\left(X^{2}{ }_{(1)}=7.81, \mathrm{p}=.005\right.$, $\mathrm{p}<.05)$.

\section{Tartışma}

Sigara kullanma durumu ile öğrencilerin kafein tüketimi arasında istatiksel olarak anlamlı ilişki elde edilmiştir $\left(X_{(2)}^{2}=6.052, \mathrm{p}=.049, \mathrm{p}<.05\right)$. Sigara kullanan öğrencilerde, riskli olarak kafein tüketen öğrencilerin oran1, normal olarak kafein tüketen öğrencilerin oranından daha yüksektir (Tablo 1). Yani riskli olarak kafein tüketme ile sigara içme ilişkilidir ve sigara içme oranı arttıkça tüketilen kafein miktarı da artmaktadır. Önce sigara veya kahve kullanmaya başlama durumu ile kafein tüketimi arasında istatistiksel olarak anlamlı ilişki bulunmuştur $\left(X^{2}(1)=5.845, \mathrm{p}=.042, \mathrm{p}<.05\right)$. Önce sigara içmeye başlayan öğrenciler tüm grubun \%27' sini oluşturuyor olmasına rağmen; riskli kafein tüketen öğrencilerin oranı, normal olarak kafein tüketen öğrencilerin oranından daha yüksektir. Önce kahve kullanmaya başlayan öğrenciler ise tüm grubun \%73'ünü oluşturuyor olmasına rağmen; normal olarak kafein tüketen öğrencilerin oranı, riskli olarak kafein tüketen öğrencilerin oranından daha yüksektir (tablo 1). Bu araştırma bize üniversite öğrencilerinin sigaranın yanında kafein tüketmeyi tercih ettiklerini ortaya koymuştur. Bickel ve arkadaşları 1992 yılında yapmış oldukları çalışmada; sadece kahve içen kişilerin kahve tüketiminin, fiyatındaki artışa bağlı olarak azalmazken, hem kahve hem de sigara içen kişilerin sigara fiyatındaki artışa bağlı olarak hem sigara hem de kahve tüketiminin azaldığını, hem kahve hem de sigara içenlerde, sadece kahve fiyatı artınca bu defa kahve tüketiminin düşerken sigara tüketiminde bir değişiklik olmadığını bulmuştur. $\mathrm{Bu}$ veriler sigara içme davranışındaki değişikliklerin kahve tüketimi ile etkilenebildiğine, ancak sigara içenlerin kahve içse de içmese de sigara içmeyi sürdürdüğüne, sigara ve kahvenin birbirini tamamlayıcı özelliği olduğuna, ancak aradaki ilişkinin simetrik olmadığına işaret etmektedir (Uzbay, 2018). Bu durum sigara içicilerindeki artmış kafein eliminasyonu ile ilişkili olabilir. Sigara içilmesi kafein metabolizmasını hızlandırır (Brown ve ark. 1988).

Silverman ve ark.' nın (1992) erişkin bireylerde kafein kapsülü ve plasebo kullanarak yaptıkları bir çalışmada, düşük veya orta miktarda kafein kullanan bireylerin, günlük kafein tüketimleri kesildiğinde yorgunluk, depresyon ve durumluk anksiyete düzeyinde artma, güçlülükte azalma, \%52 oranında orta derecede veya şiddetli başağrısı deneyimledikleri bulunmuştur (Khorshid ve Sarı, 2013). Üniversite öğrencileri üzerinde yapılan bu çalışmada ise; kafein tüketilmediğinde ya da az tüketildiğinde 24 saat aralığında görülen belirtilerden depresif $\mathrm{mod} / \mathrm{sinirlilik}$ belirtisi ile kafein tüketimi arasında ilişki anlamlı bulunmuş olup, bu belirti oranları riskli kafein tüketimi yapan öğrencilerde daha yüksek bulunmuştur (tablo 2). Son olarak kafein tüketilmediğinde ya da az tüketildiğinde 24 saat aralığında görülen belirtilerden konsantrasyon zorluğu belirtisi ile riskli kafein tüketimi arasında ilişki anlamlıdır ve bu belirti oranları riskli kafein tüketimi yapan ögrencilerde daha yüksektir (tablo 2).

Besinlerin duyularımızı, dolayısıyla sinir sistemimizi uyarma şekilleri gastronominin, gıda bilimi ve nörolojiye hakim bilim insanlarını bir araya getirerek, beynimizin yediklerimizi nasıl algıladığı, bunun toplumsal ve psikolojik sonuçları, yemek yeme alışkanlıkları, duygular, anılar, bağımlılık üzerine etkileri ve beynimizin yemekleri nasıl algıladığından hareketle, bu algıyı kandırmaya yönelik alan ise nörogastronominin alanıdır (Yıldız, 2016). Günümüzde çok iyi üniversitelerin çok iyi bölümlerini bitirip beş yıldızlı otellerde şef olarak çalışan pek çok eğitimli insan vardır. Bunlardan bazıları kimyacı 
olup, hangi baharatın ya da aromanın hangi yemeğe katıldığında nasıl bir kimyasal etkileşime geçerek nasıl bir lezzete dönüştüğü ve bunun insanlar üzerinde nasıl bir etki yarattı̆̆ının kimya bilgisi gerektirdiğgi görüşünü savunmaktalar. Buradan hareketle bir kez daha bağımlılığın, gıda, beyin, algı, duygular, anılar, özendirici figürlerin kullanımı ve psikolojimizle çok yakından ilişkisi olduğunu söyleyebiliriz.

Oxford Üniversitesi fizik bölümünün başkanlığını yapmış olan Prof. Nicholas Kurti, 2. Dünya Savaşı sırasında atom bombası üzerine çalışmış iyi bir aşçıydı ve en sevdiği hobisi yemek yapmaktı. Prof. Kurti "Mutfaktaki Fizikçi" isimli tebliğinde "bilim olarak yıldızların içindeki 1s1 derecesini biliyoruz ama ne yazık ki bir suflenin içindeki 1S1 derecesini bilmiyoruz" şeklinde sitemde bulunmuştur. Kurti bununla yüzyıllardır gelişerek devam eden mutfak kültürünün, aslında bilimsellikten ne kadar uzak, tamamen geleneksel yöntemler ile hayatını devam ettirdiğini ifade etmektedir (Batu, 2017). Günümüzde geleneksel olarak devam eden ve Türk kültürünü temsil eden çay ve Türk kahvesinin sosyal ve keyif verici yönünün dişında, bilimsel olarak başka etkilerinden habersiz yaşamaktayız.

Aslında gündelik hayatta çok sık duyduğumuz "ben çay tiryakisiyim" demenin, ben kafein bağımlısıyım demenin başka bir yolu olduğunu, gene bugün "kahvemi içmedim başım ağrıyor" söyleminin, kafein yoksunluğu çekiyorum la aynı şey olduğunu söyleyebiliriz. Küçer (2010) tarafından 156 üniversite öğrencisi ile yapılan bir çalışmada, günlük kafein tüketimi ile kafein tüketiminin kesilmesine bağlı yoksunluk belirtileri arasında bir ilişki bulunmuştur. Ameliyat sonrası görülen baş ağrısının, vücuttaki kafein düzeyinin düşmesine bağlı kafein yoksunluğu olduğu (Coşkunol, 2018) konusunda görüşler mevcuttur.

Türk toplumu için günün her saati zevkle içilen ve konukseverliğin simgesi olan çay $\% 65$ evde, \%13 iş yerinde, $\% 11$ misafirlikte, $\% 5$ kafede, $\% 4$ kahvelerde ve \%2 okullarda tüketilmektedir (Güneş, 2012). Kafein içeren yiyecek ve içeceklerin çevremizde bu kadar yaygın ve her an kullanıma hazır bir şekilde bulunması, kafeinin yaşantımızda ne kadar önemli ve acil bir ihtiyaç olduğunu bir kez ortaya koymaktadır.

\section{Sonuç ve Öneriler}

Sigara kullanıp kullanmama ve önce sigara ya da kahve kullanmaya başlama durumu ile öğrencilerin kafein tüketimi arasında istatiksel olarak anlamlı ilişki elde edilmiştir. Sigara kullanım oranının artması kafein tüketim miktarını da artırmaktadır. Önce sigara içmeye başlayan öğrenciler için; riskli olarak kafein tüketen öğrencilerin oranı normal olarak kafein tüketen öğrencilerin oranından daha yüksektir.

Öğrencilerde kafein tüketiminin olmadığı yada az olduğu durumlarda 24 saat içinde görülen depresif mod ve sinirlilik belirtisi ile konsantrasyon zorluğu belirtisinin görülüp görülmemesi ile kafein tüketimi arasında istatiksel olarak anlamlı ilişki elde edilmiştir. Riskli olarak kafein tüketmek öğrencilerin depresif mod/sinirlilik ve konsantrasyon zorluğu durumlarının görülme oranlarını da artırmaktadır.
Sonuç olarak; Araştırma sonunda üniversite öğrencilerinin \%20' sinin riskli kafein tüketimi kriterlerini karşıladığı ve kafein bağımlılı̆̆ 1 için risk grubunda oldukları bulunmuştur.

-Aileler ve toplum kafein, kafein bağımlılığı ile zeminini oluşturan riskli tüketim konusunda eğitilmeli, çocuklukta çikolata ve kolalı içecekler ile ilk basamağın atıldığ gerçeği aşılanmalıdır.

-Beslenme uzmanları ve diyetisyenlerin dikkati kafein gerçeğine çevrilmeli, kafein içeren tüm ürünlerin bir listesi hazırlanmalı, yiyecek ve içeceklerdeki kafein miktarları dikkatli gözden geçirilmeli ve beslenme programları hazırlanırken bunlar göz önünde bulundurulmalidır.

-Kafeinin etkileri, riskli tüketim, kafein tüketilmediğinde yada az tüketildiğinde görülen belirtiler konusunda toplum eğitilmeli. Bunun için Sağlık Bakanlığı tarafindan halk sağlığı taramalarında kullanılmak üzere, kafein tüketimi ve kaynaklarını değerlendiren birtakım test ve tarama şablonları hazırlanabilir, broşürler basılabilir.

-Kafeinin etkileri ile tüketilmediğinde ya da az tüketildiğinde görülen belirtilerin, diğer hastalık belirtileri ile karıştırılmaması konusunda sağlı profesyonellerinin bilinçlendirilmesi sağlanmalıdır.

-Doktorların kullandığ Formlarına ayrıca hemşirelerin kullandığı Hemşirelik Tanı Formlarına günlük kafein tüketimi ve kaynakları ile riskli tüketimine ilişkin maddeler eklenmeli ve hastalar belirtiler yönünden izlenmelidir.

-Ülkemizde olduğu gibi tüm dünyada birinci sırada tüketilen kafein kaynağı çay ve kahvedir. Kafeinsiz kahve üretildi fakat beklenen ilgiyi görmedi. Çaydan kafein ayrıştırılarak kafeinsiz çay üretilebilir. Bunlara ilişkin özendirici reklamlar yayınlanabilir.

-Kafein içeren ürünlere ilişkin özendirici reklamlara reklam yasağı getirilebilir.

-Kafein bağımlılığı ve zeminini hazırlayan riskli tüketimin ileride endemik bir soruna dönüşmesinin önüne geçmek için gıda bilimi, gastronomi, nörogastronomi, kimya, psikoloji, sosyoloji gibi bilim dallarının birleşimi ile, bu alanlarda yetişmiş bilim insanlarının bir araya gelerek yapacağı bilimsel çalışma ve üretilecek ortak politikalara ihtiyaç vardır.

-Bütün kafein içeren ürünler ile içerdikleri kafein miktarlarını, güvenli kullanım, riskli kullanım sınırlarını ve tehlikeli kullanım miktarlarını halka duyuracak kamu spotlarına ihtiyaç vardır.

-En yüksek kafein kaynaklarının ilk sırasında çay ve kahve gelmektedir. Unesco' nun SOKÜM listesine kültürel mirasımız olarak girmeyi başarmış bir Türk kahvesi ve tiryakiliğimiz olan çay ile ilgili farkındalık çalışmalarında dikkatli olunmalı, geleneksel kültürümüzle çelişmeyecek, toplumun refleks tepkileri de göz önüne alınarak; Sağlık Bakanlığı, Millî Eğitim Bakanlığı, Turizm Bakanlığı gibi bakanlıklar ve YÖK düzeyinde ulusal politikalar oluşturulmalıdır.

-Bu ve benzeri çalışmaların daha geniş bir örneklem ve farklı değişkenler ile yapılması, daha geneli temsil etmesi bakımından daha etkili sonuçlar alınmasına ve daha farklı çözüm önerileri geliştirilmesine katkı sağlayacaktır. 


\section{Kaynaklar}

Batu, A. (2017). Moleküler Bakış Açısıyla Gıdaların Tat Ve Aroma Algilar1. Aydin Gastronomi, 1 (1), 25-36.

Bolton S, N. G. (1981) Caffeine: Psychological Effects, Use And Abuse. Orthomolecular Psychiatry, 10: 3, 202-211.

Brown C.R, Jacob P., Wilson M., Beowitz N.L.(1988). Changes In Rate And Pattern Of Caffeine Metabolism After Cigarette Abstinence. Clinical Pharmacology Therapeutics, 43(5), 488491.

Coşkunol, H. (2018). Temel Ve Klinik Psikiyatri. Oğuz Karamustafalığlu (Ed.), Kafein (S.585-590). Ankara: Güneş Tıp Kitapevleri.

Eskigün, S., Bayrak, A. (2006). Bazı Gıdalarda Kafein Ve Teobromin Düzeyleri. Gıda, 31 (1), 49-57.

Güneş, S. (2012). Türk Çay Kültürü Ve Ürünleri. Millî Folklor, 93, 234-251.
Hancı, M., Bakırcı, S., Bayram, S., Karahan, S., Kaya, E. (2013). Türk Kahvesi Ve Türkiye'de Satılan Baziçceceklerdeki Kafein Miktarları. Düzce Tıp Dergisi, 15(3), 34-38.

Khorshıd, L., Sarı, D. (2013). Üniversite Çalışanlarında Kafein Tüketimi. Ege Üniversitesi Hemşirelik Fakültesi Dergisi,29(1), 45-59.

Küçer, N. (2010). The Relationship Between Daily Caffeine Consumption And Withdrawal Symptomps:A QuetionnaireBased Study. Tübitak, 40(1),105-108.

Pennay, A. E., Lubman, D. I. (2012). Energy Drinks: Health Risks And Toxicity. The Medical Journal Of Australia, (1967), 442-447.

Uzbay, T. (2015). Madde Bağımlılı̆̆ı: Tüm Boyutlarıyla Bağımlılık Ve Bağımlılık Yapan Maddeler (1. Baskı). İstanbul: İstanbul Tip Kitabevi.

Yildı, Ö. $\quad$ (2016). Nörogastronomi. Http://Rmftf.Deu.Edu.Tr/Files/Nrogastronomia1.Pdf. Erişim Tarihi: 22.07.2019. 